Article

\title{
Butyronitrile-Based Electrolytes for Fast Charging of Lithium-Ion Batteries
}

\author{
Peter Hilbig ${ }^{1}$, Lukas Ibing ${ }^{1}$, Martin Winter ${ }^{1,2}$ and Isidora Cekic-Laskovic ${ }^{2, *}$ \\ 1 MEET Battery Research Center/Institute of Physical Chemistry, University of Münster, Corrensstrasse 46, \\ 48149 Münster, Germany \\ 2 Helmholtz-Institute Münster, IEK-12, Forschungszentrum Jülich GmbH, Corrensstrasse 46, \\ 48149 Münster, Germany \\ * Correspondence: i.cekic-laskovic@fz-juelich.de
}

Received: 19 June 2019; Accepted: 18 July 2019; Published: 25 July 2019

check for updates

\begin{abstract}
After determining the optimum composition of the butyronitrile: ethylene carbonate: fluoroethylene carbonate (BN:EC:FEC) solvent/co-solvent/additive mixture, the resulting electrolyte formulation (1M LiPF 6 in BN:EC (9:1) + 3\% FEC) was evaluated in terms of ionic conductivity and the electrochemical stability window, as well as galvanostatic cycling performance in NMC/graphite cells. This cell chemistry results in remarkable fast charging, required, for instance, for automotive applications. In addition, a good long-term cycling behavior lasts for 1000 charge/discharge cycles and improved ionic conductivity compared to the benchmark counterpart was achieved. XPS sputter depth profiling analysis proved the beneficial behavior of the tuned BN-based electrolyte on the graphite surface, by confirming the formation of an effective solid electrolyte interphase (SEI).
\end{abstract}

Keywords: lithium-ion batteries; non-aqueous electrolyte; nitrile-based solvents; butyronitrile; SEI forming additives; fast charging

\section{Introduction}

Thanks to their excellent performance characteristics, lithium ion battery (LIB) cells find application in a broad spectrum of different fields, comprising the consumer and automotive industries as well as application in small portable devices, like mobile phones or laptops [1-4]. The main reason behind the broad field of application relates, among other reasons, to the high specific energy and energy density of LIBs [5-7] and the numerous cell materials, that can be employed [8].

In standard LIBs, organic carbonate-based non aqueous aprotic electrolytes are employed. Although given as state of the art electrolytes, they display several disadvantages (e.g., moderate ionic conductivity and low flash points) [9-12]. To further advance state of the art battery electrolytes, many solvent classes were comprehensively investigated to replace organic carbonates [9,13-24]. Nitriles and other cyano-compounds display high ionic conductivity as well as low temperature cycling performance [25-34]. Nevertheless, many examples of this class of compounds are known for being incompatible with metallic lithium and not able to form an effective solid electrolyte interphase (SEI) on graphite [35-40]. For this reason, the presence of SEI forming electrolyte additive(s) is inevitably required to enable their application in graphite based LIBs [41].

In the case of organic carbonate-based electrolytes, ethylene carbonate (EC) is typically involved in the formation of the SEI on graphite in the first charge/discharge cycles [42]. In addition to EC [43,44], other SEI forming agents on graphite were reported in the literature, e.g., lithium difluoro-(oxalate)borate (LiDFOB), vinylene carbonate (VC) or fluoroethylene carbonate (FEC) [45-53] and many more. Among them, VC and FEC are preferred as SEI additives on graphite anodes for organic carbonate-based electrolytes $[9,13]$. 
In this contribution, butyronitrile (BN)-based electrolytes containing EC, FEC or both as co-solvents/functional additives are considered for fast charging application in lithium-nickelmanganese-cobalt-oxide (NMC)/graphite cells. The investigations were mainly performed in full cell setup. The optimum BN:EC:FEC solvent/co-solvent-functional additive ratio was investigated in terms of long-term cycling and C-rate performance in NMC/graphite cells. The obtained electrochemical results were correlated to the surface analysis of the graphite electrodes via XPS measurements.

\section{Experimental Section}

\subsection{Electrolyte Formulation}

All considered electrolytes were formulated using volume percent (vol.\%) in an argon-filled glovebox (MBRAUN, Garching, Germany) with a water and oxygen content below $0.1 \mathrm{ppm}$. BN 99\% (MERCK, Darmstadt, Germany), lithium hexafluorophosphate ( $\mathrm{LiPF}_{6}, \mathrm{BASF}$, battery grade, Ludwigshafen, Germany), FEC (BASF, battery grade, Ludwigshafen, Germany) and EC 99.8\% anhydrous (MERCK, Darmstadt, Germany) were used as received. As reference electrolyte, 1M $\mathrm{LiPF}_{6}$ in EC:DMC (1:1 wt.\%) (LP30, BASF, battery grade, Ludwigshafen, Germany) was used.

\subsection{Preparation of T44 Graphite and Lithium Manganese Oxide Electrodes}

The composition of graphite electrodes was as follows: $87 \mathrm{wt} . \%$ T44 graphite (Imerys, Paris, France) 8 wt.\% polyvinylidene difluoride (PVdF, Arkema, Colombes, France) and 5 wt.\% conductive additive Super C65 (Imerys, Paris, France). T44 graphite was used as the active material due to its high BET surface area, leading to a pronounced reduction of the electrolyte [54] The $\mathrm{LiMn}_{2} \mathrm{O}_{4}$ (LMO) electrodes were composed of $80 \mathrm{wt}$.\% LMO (Toda, Hiroshima, Japan), $10 \mathrm{wt} . \%$ PVdF and $10 \mathrm{wt} . \%$ Super C65. In the fabrication process of the electrodes, PVdF was dissolved in $\mathrm{N}, \mathrm{N}$-dimethylformamide $99.8 \%$ anhydrous (DMF, Alfa Aesar, Haverhill, MA, USA). Subsequently, conductive additive (Super C65) and active material (T44 or LMO) were added to the solution and mixed with a dissolver. The suspension was thereafter coated with a special film applicator, on a copper foil (negative electrodes; T44; $120 \mu \mathrm{m}$ wet thickness) and on aluminum foil (positive electrodes; LMO; $100 \mu \mathrm{m}$ wet thickness). The coated foils were dried in an oven (Binder, Tuttlingen, Germany) at $80{ }^{\circ} \mathrm{C}$ overnight. The obtained electrodes were cut with a punching tool (Hohsen Corp. Osaka, Japan) into a diameter of $12 \mathrm{~mm}$ and thereafter dried at $120{ }^{\circ} \mathrm{C}$ in vacuum for $24 \mathrm{~h}$ in a Buchi Glass Oven 585 with a rotary vane pump vacuum (Büchi, Flawil, Switzerland). After weighting (Sartorius laboratory balance; Sartorius, Göttingen, Germany), the resulting electrodes had an active mass loading between 2.5 and $3 \mathrm{mg} \mathrm{cm}^{-2}$ [53]. For the investigations in the full-cell setup, balanced NMC111 (Litarion, Kamenz, Germany) and graphite electrodes (Litarion, Kamenz, Germany) both $12 \mathrm{~mm}$ diameter, were used.

\subsection{Electrochemical Measurements}

\subsubsection{Cell Set-Up}

The electrochemical measurements were performed in a two electrode, coin cell (2032) (Hohsen Corp. Osaka, Japan), setup as well as in three-electrode T-cell setup (Swagelok ${ }^{\circledR}$ Solon, OH, USA). The NMC was used as the working electrode (WE), graphite as the counter electrode (CE), whereas lithium foil (Albemarle, Charlotte, NC, USA) was taken as the reference electrode (RE).

\subsubsection{Linear Sweep Voltammetry Measurements}

The electrochemical stability window of the considered BN-based electrolytes was determined by means of linear sweep voltammetry (LSV) using a VMP3 potentiostat (Bio-Logic, Seyssinet-Pariset, France). A lithium manganese oxide (LMO) based electrode was used as WE, whereas lithium foil was used as the CE and RE. The measurements were performed in the potential range between the 
open circuit potential (OCP) and $5.0 \mathrm{~V} \mathrm{vs.} \mathrm{Li}^{\prime} / \mathrm{Li}^{+}$, using a scan rate of $100 \mu \mathrm{V} \mathrm{s}{ }^{-1}$ at room temperature $\left(20^{\circ} \mathrm{C}\right)$.

\subsubsection{Cyclic Voltammetry Measurements}

Cyclic voltammetry (CV) measurements were carried out at room temperature, using a Bio-Logic VMP3 potentiostat, in the potential range from $0.02-2.00 \mathrm{~V} \mathrm{vs}$. $\mathrm{Li} / \mathrm{Li}^{+}$. The cells were cycled with a scan rate of $20 \mu \mathrm{V} \mathrm{s}^{-1}$. T44 graphite was used as WE. Lithium foil was used as the CE and RE.

\subsubsection{Galvanostatic Measurements}

Measurements were carried out at $20^{\circ} \mathrm{C}$ by means of battery cycler (MACCOR Series 4000 , Tulsa, OK, USA). The cathode limited NMC/graphite cells ( $20 \%$ capacity-oversized anode) were cycled for five formation cycles at $0.1 \mathrm{C}$ in a voltage range between 3.00-4.30 V. After the formation sequence, cells were cycled with a charge and discharge rate of $372 \mathrm{~mA} \mathrm{~g}^{-1}$ (1C). For the C-rate evaluation, $\mathrm{C}$-rate of the charge step, the discharge step and of both the charge and the discharge steps was always altered after five cycles in the following manner: five cycles with a $\mathrm{C}$-rate of $1 \mathrm{C}$ followed by a $\mathrm{C}$-rate of $0.2 \mathrm{C}, 1 \mathrm{C}, 2 \mathrm{C}$, 5C, 10C, 15C, 20C followed by 30 cycles with a C-rate of 1C. During the performance assessment of the charge behavior, the C-rate of the charge step was altered, and the C-rate of the discharge step was set to $1 \mathrm{C}$. The performance assessment was based on the discharge capacity. In the discharge performance evaluation, the C-rate of the discharge step was altered, and the C-rate of the charge step was set to $1 \mathrm{C}$. In the charge/discharge performance rating, the C-rate of the charge step as well as the C-rate of the discharge step were altered in afore mentioned way. During the $5 \mathrm{C}$ performance evaluation, the C-rate was set to $1 \mathrm{C}$ after the formation sequence for 10 cycles followed by 95 charge/discharge cycles with $5 \mathrm{C}$ for each charge and discharge step. During the long-time cycling evaluation, the C-rate of the charge and discharge step was set to $1 \mathrm{C}$ after the formation procedure. Furthermore, a current-limited CV step of $0.05 \mathrm{C}$ was introduced to the galvanostatic cycling procedure, for the 1000 cycle measurement.

\subsection{Conductivity Measurements}

AC impedance measurements were used to determine the conductivity of the considered BN-based electrolyte formulations. All measurements were carried out on a Solartron 1260A (AMETEK, Berwyn, PA, USA) impedance gain phase analyzer, connected to a Solartron 1287A (AMETEK, Berwyn, PA, USA) potentiostat using a customized cell having two stainless steel disk-electrodes. A frequency range from $1 \mathrm{kHz}$ to $1 \mathrm{MHz}$ using an AC amplitude of $20 \mathrm{mV}$ was applied to the cell for each temperature $\left(-40\right.$ to $\left.60^{\circ} \mathrm{C}\right)$, which was regulated via a climate chamber.

\subsection{X-ray Photoelectron Spectroscopy (XPS) Analysis}

For the XPS measurements, an AXIS Ultra DLD (Kratos, Shimadzu Corporation, Kyoto, Japan) was used. An area of $300 \mu \mathrm{m} \times 700 \mu \mathrm{m}$ was irradiated using a filament voltage of $12 \mathrm{kV}$, an emission current of $10 \mathrm{~mA}$ and a pass energy of $20 \mathrm{eV}$. The obtained spectra were calibrated against the adventitious carbon signal at $284.5 \mathrm{eV}$. For the XPS sputter depth profiling measurements a sputter crater diameter of $1.1 \mathrm{~mm}$, an emission current of $8 \mathrm{~mA}$, and a filament voltage of $0.5 \mathrm{kV}$ as well as a pass energy of $40 \mathrm{eV}$ and a $110 \mu \mathrm{m}$ aperture were applied. The fitting of the resulted spectra was performed with the help of CasaXPS.

\section{Results and Discussion}

Nitrile-based electrolytes are known to deliver higher ionic conductivity values compared to the state of the art organic carbonate-based counterparts (Figure 1) [55]. This solvent class is particularly interesting when it comes to fast charging behavior of LIBs. Having in mind that BN is not stable against metallic lithium or graphite, a SEI-forming co-solvent was added to the BN-based electrolyte. 
With this in line, $1 \mathrm{M} \mathrm{LiPF}_{6}$ in BN:EC (1:1) as well as $1 \mathrm{M} \mathrm{LiPF}_{6}$ in BN:FEC (1:1) electrolyte formulations were compared with the $1 \mathrm{M} \mathrm{LiPF}_{6}$ in EC:DMC (1:1) electrolyte, taken as reference.

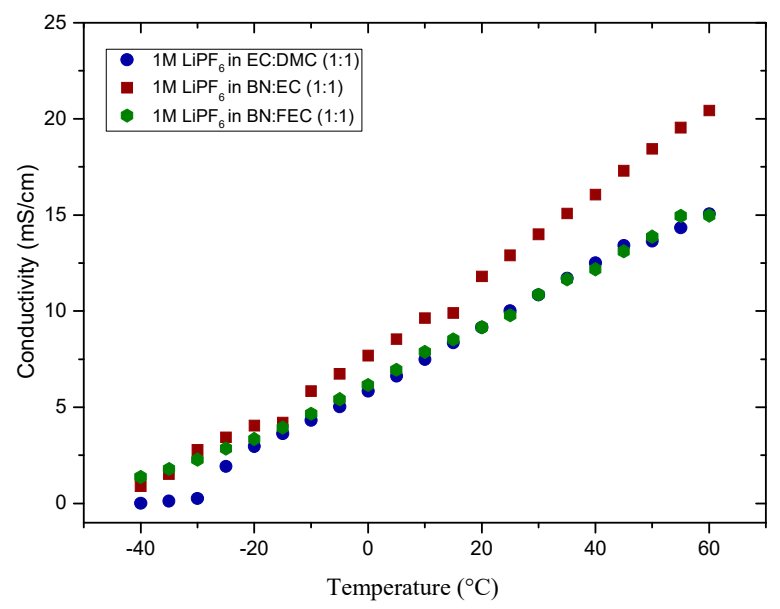

Figure 1. Temperature dependent conductivity measurements of $1 \mathrm{M} \mathrm{LiPF}_{6}$ in EC:DMC (1:1), $1 \mathrm{M} \mathrm{LiPF}_{6}$ in $\mathrm{BN}: \mathrm{FEC}(1: 1)$ and $1 \mathrm{M} \mathrm{LiPF}_{6}$ in $\mathrm{BN}: \mathrm{EC}(1: 1)$, in the temperature range from -40 to $60^{\circ} \mathrm{C}$.

When using EC as co-solvent, the BN-based electrolyte delivers higher conductivity values compared to the $1 \mathrm{M} \mathrm{LiPF}_{6}$ in EC:DMC (1:1) electrolyte (Figure 1). Especially at low temperature $\left(0{ }^{\circ} \mathrm{C}\right)$, the conductivity of the considered BN:EC-based electrolyte is at least $32 \%$ higher $(7.69 \mathrm{mS} / \mathrm{cm})$ compared to the organic carbonate-based counterpart $(5.83 \mathrm{mS} / \mathrm{cm})$. Substitution of EC with FEC leads to a decreased conductivity (from $11.80 \mathrm{mS} / \mathrm{cm}$ to $9.16 \mathrm{mS} / \mathrm{cm}$ ) at $20^{\circ} \mathrm{C}$. In the temperature range of $20^{\circ} \mathrm{C}$ to $60{ }^{\circ} \mathrm{C}$, the conductivity of $1 \mathrm{M} \mathrm{LiPF}_{6}$ in EC:DMC (1:1) is equal to the conductivity values of the $1 \mathrm{M} \mathrm{LiPF}_{6}$ in $\mathrm{BN}$ :FEC (1:1) electrolyte. In contrast to the high conductivity of the BN:EC mixture, the conductivity of the BN:FEC mixture was shown to be quite poor. The high conductivity of the BN:EC mixture-based electrolytes makes them suitable for fast charging $(>1 C)$.

The conductivity values of the investigated electrolytes can be explained by means of relevant physicochemical properties of the used solvents. The conductivity is related to the viscosity and to the relative permittivity of the electrolyte formulation. The ion mobility is linked to the viscosity whereas the salt dissociation capability is related to the relative permittivity. To obtain a high conductivity, the viscosity of the electrolyte formulation should be low, and the relative permittivity must be high enough to ensure a sufficient dissolution of the conducting salt.

To determine the oxidative stability of the BN-based electrolytes, compared to the reference electrolyte, corresponding voltammograms were recorded using LMO as WE (Figure 2). A content of $50 \%$ of FEC was chosen to overcome the instability of nitriles towards metallic lithium and to ensure the passivation of the metallic lithium $[13,61]$. Whereas with organic carbonate-based electrolyte $\mathrm{Li}$ metal is stable, [62] with an EC content of only $50 \%$, in the mixture the degradation of the electrolyte could not be inhibited. Therefore, EC:BN mixtures could not be investigated in combination with lithium metal. Nevertheless, this mixture should display the same oxidative stability (as confirmed by later full cell experiments). With $1 \mathrm{M} \mathrm{LiPF}_{6}$ in EC:DMC (1:1) as reference electrolyte, the maxima of the de-insertion peaks of $\mathrm{LMO}$ are positioned at. $4.05 \mathrm{~V}$ vs. $\mathrm{Li} / \mathrm{Li}^{+}$and $4.16 \mathrm{~V} \mathrm{vs.} \mathrm{Li}^{-\mathrm{Li}^{+}}$[63]. In this setup, the reference electrolyte was found to be electrochemically stable up to $4.90 \mathrm{~V} \mathrm{vs.} \mathrm{Li}^{-\mathrm{Li}^{+}}$[64].

Compared to the reference electrolyte, the voltammogram of the cell containing $1 \mathrm{M} \mathrm{LiPF}_{6}$ in BN:FEC (1:1) displays de-insertion peak maxima of $\mathrm{LMO}$ at $4.05 \mathrm{~V}$ vs. $\mathrm{Li} / \mathrm{Li}^{+}$and $4.19 \mathrm{~V} \mathrm{vs.} \mathrm{Li} / \mathrm{Li}^{+}$. This electrolyte formulation shows electrochemical stability up to $4.50 \mathrm{~V} \mathrm{vs}$. $\mathrm{Li}^{\prime} / \mathrm{Li}^{+}$, which is much higher compared to other literature known nitriles [65]. Furthermore, this result fits well with literature showing known density functional theory (DFT) calculations [55]. This behavior makes the combination of BN-based electrolytes with cathode materials, such as lithium nickel cobalt aluminum oxide (NCA) and NMC possible. 


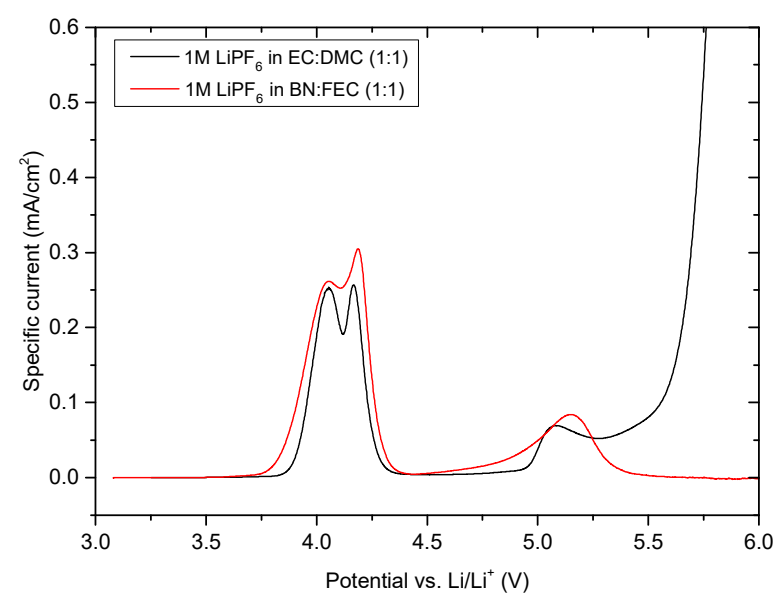

Figure 2. Linear sweep voltammograms of cells containing $1 \mathrm{M} \mathrm{LiPF}_{6}$ in $\mathrm{BN}: \mathrm{FEC}(1: 1)$ and $1 \mathrm{M} \mathrm{LiPF}_{6}$ in EC:DMC (1:1) (wt.\%), LMO as WE, and $\mathrm{Li}$ as $\mathrm{CE}$ and $\mathrm{RE}$, at scan rate of $100 \mu \mathrm{V} \mathrm{s}^{-1}$ at room temperature.

Cyclic voltammetry measurements in $\mathrm{T} 44$ graphite/lithium cells containing $1 \mathrm{M} \mathrm{LiPF}_{6}$ in various $\mathrm{BN}: \mathrm{FEC}$ solvent/co-solvent ratios were performed to determine the reductive stability of the considered electrolyte formulations vs. the anode (Figure 3).

The decomposition of FEC starts at a potential of $1.60 \mathrm{~V} \mathrm{vs.} \mathrm{Li} / \mathrm{Li}^{+}$, reaching the peak maximum at a potential value of $1.50 \mathrm{~V}$ vs. $\mathrm{Li} / \mathrm{Li}^{+}$(Figure 3a-d). Due to the SEI formation in presence of FEC, the decomposition of the $1 \mathrm{M} \mathrm{LiPF}_{6}$ in BN:FEC (1:1) (Figure 3a), $1 \mathrm{M} \mathrm{LiPF}_{6}$ in BN:FEC (6:4) (Figure 3b), $1 \mathrm{M} \mathrm{LiPF}_{6}$ in BN:FEC (7:3) (Figure 3c), $1 \mathrm{M} \mathrm{LiPF}_{6}$ in BN:FEC (8:2) (Figure 3d) electrolyte formulations are inhibited, thus leading to the reversible intercalation and deintercalation of lithium ions into the graphite host structure, as indicated by the presence of the corresponding peaks (starting at a potential of $\left.0.30 \mathrm{~V} \mathrm{vs.} \mathrm{Li} / \mathrm{Li}^{+}\right)$. Compared to the aforementioned electrolyte formulations, $1 \mathrm{M} \mathrm{LiPF} 6$ in BN:FEC (9:1) electrolyte (Figure 3e) is not able to form an effective SEI on graphite and results in a severe decomposition. As a consequence, no intercalation/deintercalation steps take place. The amount of FEC seems not to be enough to protect the BN against decomposition on both T44 graphite and lithium electrode. Compared to FEC, the decomposition of in the $1 \mathrm{M} \mathrm{LiPF}_{6}$ in EC:DMC (1:1) (Figure 3f) mixture starts at $0.9 \mathrm{~V}$ vs. $\mathrm{Li} / \mathrm{Li}^{+}$and the peak maximum is reached at $0.80 \mathrm{~V}$ vs. $\mathrm{Li} / \mathrm{Li}^{+}$.

To prove the fast charging ability of the NMC/graphite cells containing afore mentioned BN-based electrolyte formulations, a C-rate evaluation up to $5 \mathrm{C}$ was performed, starting with five formation cycles at $0.1 \mathrm{C}$. After the formation, 10 cycles at $1.0 \mathrm{C}$ were conducted, followed by 95 charge/discharge cycles with a C-rate of 5C. The obtained results are shown in Figure 4. As depicted in Figure 4a, the $\mathrm{NMC}$ /graphite cell containing $1 \mathrm{M} \mathrm{LiPF}_{6}$ in $\mathrm{BN}$ :EC (1:1) electrolyte, reaches a Coulombic efficiency of $87 \%$ in the first cycle (see Meister et al. for the meanings of efficiencies) [66]. The specific discharge capacity amounts to $176 \mathrm{mAh} / \mathrm{g}$ with a C-rate of $0.1 \mathrm{C}$ in the first five cycles, whereas in the consecutive 10 charge/discharge cycles, a specific discharge capacity of $153 \mathrm{mAh} / \mathrm{g}$ with a Coulombic efficiency of $99 \%$ is achieved. After 15 cycles, the C-rate evaluation was started with a C-rate of 5C for each charge and discharge step for the consecutive 95 charge/discharge cycles. The specific discharge capacity displays a negligible fading and drops from $76 \mathrm{mAh} / \mathrm{g}$ in the 30th cycle to $68 \mathrm{mAh} / \mathrm{g}$ in the 110th cycle. The Coulombic efficiency drop in the 6th and 16th cycle is related to the change of the C-rate and observed in each chart in Figure 4. The cell containing $1 \mathrm{M} \mathrm{LiPF}_{6}$ in BN:EC (7:3) $+1 \%$ FEC electrolyte formulation displays a first cycle Coulombic efficiency of $87 \%$, as illustrated in Figure $4 \mathrm{~b}$. The specific discharge capacity amounts to $177 \mathrm{mAh} / \mathrm{g}$ for each cycle with a C-rate of 0.1C. A specific discharge capacity of $155 \mathrm{mAh} / \mathrm{g}$ with a Coulombic efficiency of $99 \%$ is reached in the following 10 charge/discharge cycles. In the C-rate evaluation, the specific discharge capacity shows a notable fading and drops from $93 \mathrm{mAh} / \mathrm{g}$ in cycle 30 to $68 \mathrm{mAh} / \mathrm{g}$ in cycle 110. The cell chemistry outlined in Figure $4 \mathrm{c}$ comprises of $1 \mathrm{M} \mathrm{LiPF}_{6}$ in BN:EC (9:1) + 3\% FEC electrolyte. The specific discharge capacity amounts to $176 \mathrm{mAh} / \mathrm{g}$ in the first five cycles using a C-rate of $0.1 \mathrm{C}$, whereas the first cycle 
Coulombic efficiency amounts to $86 \%$. Unlike other considered electrolyte formulations displayed in Figure 4,99\% Coulombic efficiency is not reached in the second but in the third cycle. The specific discharge capacity in the consecutive 10 charge/discharge cycles amounts to $155 \mathrm{mAh} / \mathrm{g}$. During the $5 \mathrm{C}$ sequence, the capacity drops down to $105 \mathrm{mAh} / \mathrm{g}$ in the 30th cycle and decreases to $100 \mathrm{mAh} / \mathrm{g}$ in the 110th cycle, without a substantial fading. The cell containing 1M LiPF 6 in EC:DMC (1:1) electrolyte formulation, (Figure 4d) displays a first Coulombic efficiency of $87 \%$. The specific discharge capacity amounts to $176 \mathrm{mAh} / \mathrm{g}$ for each cycle with a C-rate of $0.1 \mathrm{C}$. The following 10 charge/discharge cycles display a specific discharge capacity of $155 \mathrm{mAh} / \mathrm{g}$ with a Coulombic efficiency of $99 \%$. In the C-rate evaluation the specific discharge capacity drops from $67 \mathrm{mAh} / \mathrm{g}$ in the 30th cycle to $64 \mathrm{mAh} / \mathrm{g}$ in the 110th cycle. A comparison between the $1 \mathrm{M} \mathrm{LiPF}_{6}$ in BN:EC (9:1) + 3\% FEC and the reference electrolyte indicates a similar cycling performance at $\mathrm{C}$-rates up to $1 \mathrm{C}$ and a superior higher performance of BN-based electrolyte at $5 \mathrm{C}$. During cycling at $5 \mathrm{C}$, the specific discharge capacity is decreased by $5 \%$ from $105 \mathrm{mAh} / \mathrm{g}$ to $100 \mathrm{mAh} / \mathrm{g}$ comparable to $4 \%$ with the reference electrolyte. In addition, the average specific discharge capacity at $5 \mathrm{C}$ is $\approx 103 \mathrm{mAh} / \mathrm{g}$ compared to $\approx 66 \mathrm{mAh} / \mathrm{g}$ for the reference electrolyte. The deviation amounts to $37 \mathrm{mAh} / \mathrm{g}(56 \%)$.
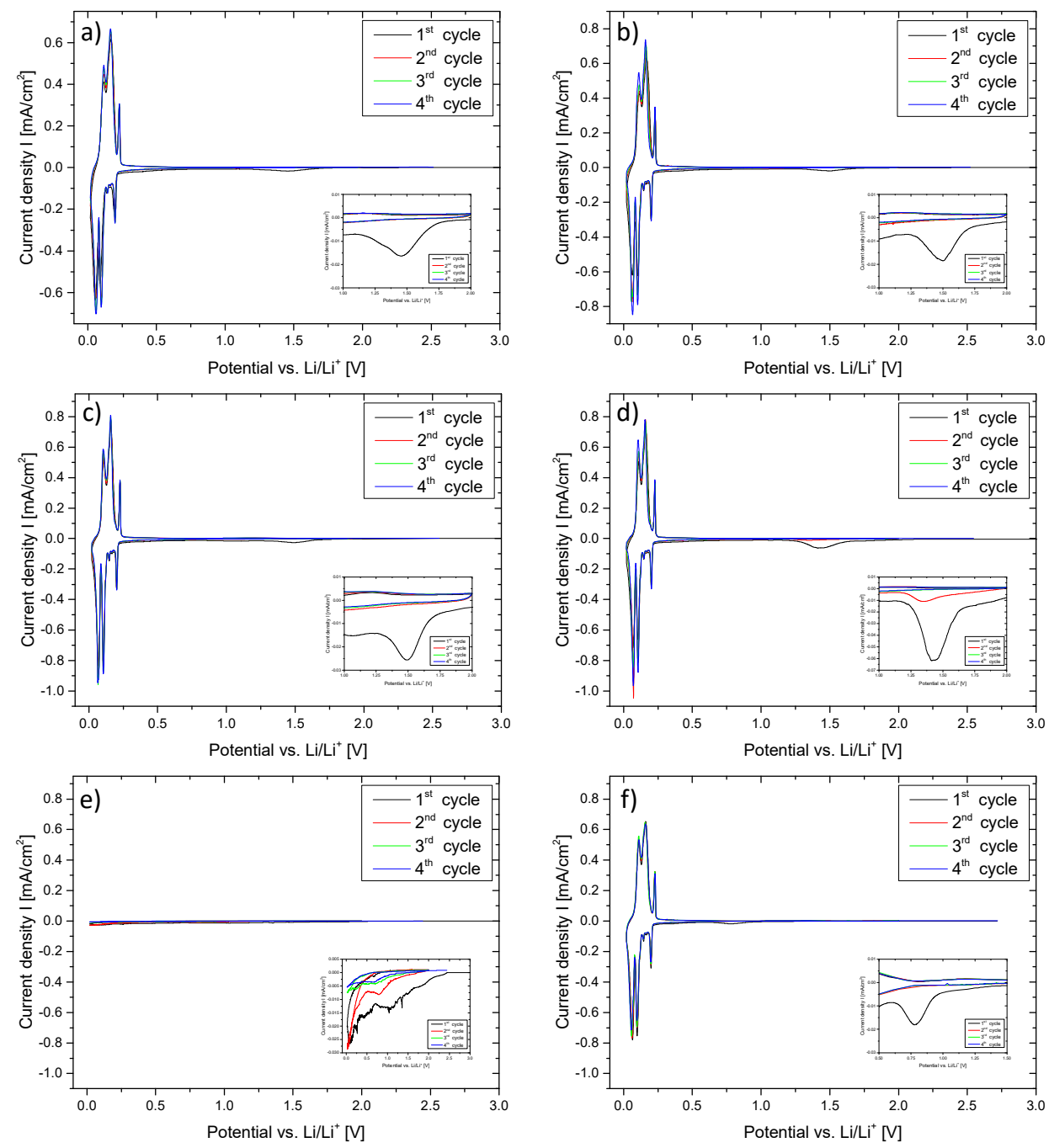

Figure 3. Cyclic voltammograms of $\mathrm{T} 44$ graphite/lithium cells containing $1 \mathrm{M} \mathrm{LiPF} 6$ in (a) $\mathrm{BN}: \mathrm{FEC}$ (1:1), (b) BN:FEC (6:4), (c) BN:FEC (7:3), (d) BN:FEC (8:2), (e) BN:FEC (9:1) and (f) EC:DMC (1:1) as electrolyte formulation, in the potential range between $0.02-2.00 \mathrm{~V} \mathrm{vs} . \mathrm{Li}^{\prime} / \mathrm{Li}^{+}$, at scan rate of $20 \mu \mathrm{V} \mathrm{s}{ }^{-1}$; insert shows the magnification of the reductive decomposition peak of fluoroethylene carbonate (FEC) at $1.5 \mathrm{~V}$ vs. $\mathrm{Li} / \mathrm{Li}^{+}$. 

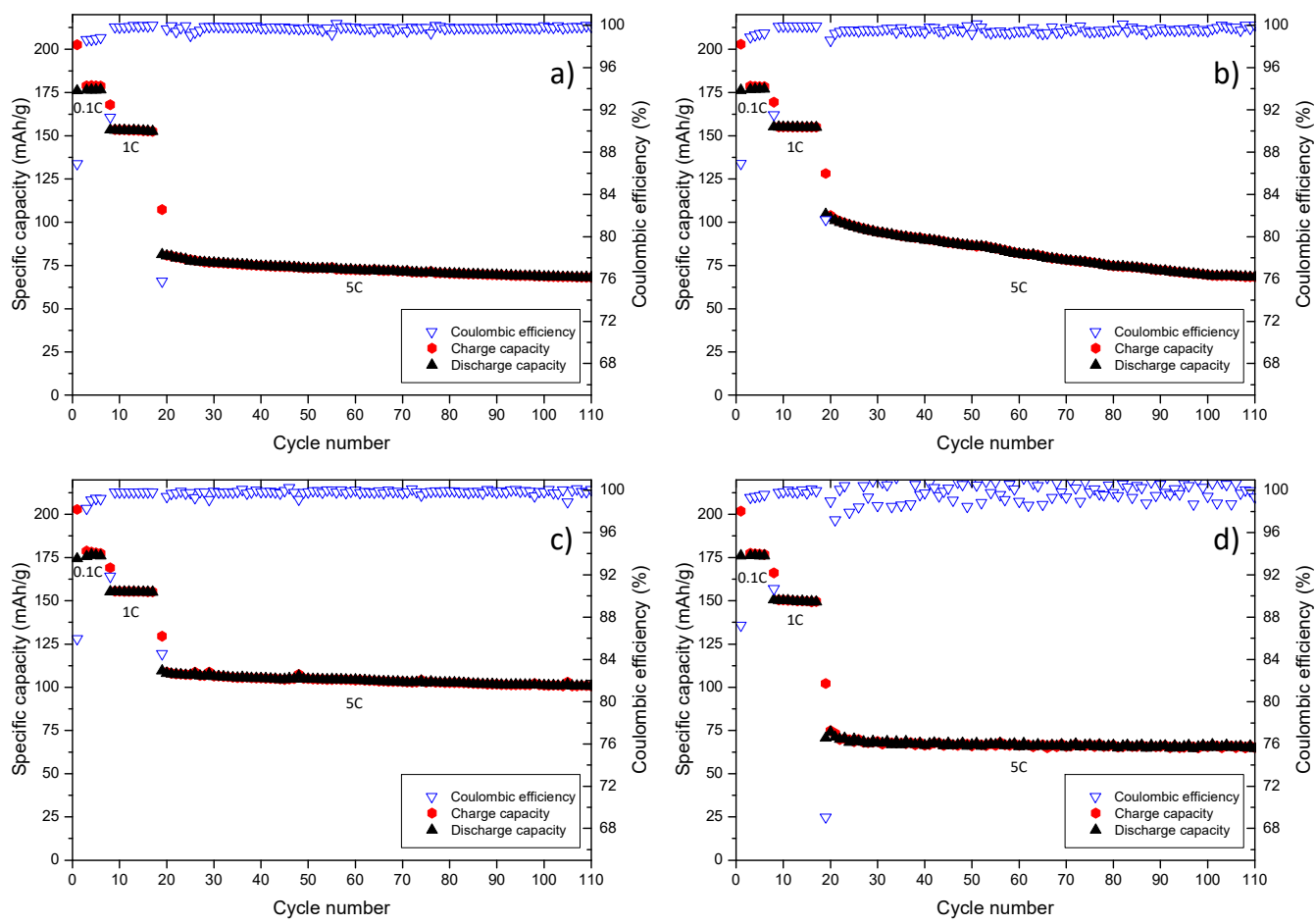

Figure 4. C-rate evaluation of the NMC/graphite cells containing (a) $1 \mathrm{M} \mathrm{LiPF}_{6}$ in $\mathrm{BN}: \mathrm{EC}(1: 1)$, (b) $1 \mathrm{M}$ $\mathrm{LiPF}_{6}$ in $\mathrm{BN}: \mathrm{EC}(7: 3)+1 \% \mathrm{FEC}$, (c) $1 \mathrm{M} \mathrm{LiPF}_{6}$ in BN:EC (9:1) + 3\% FEC and (d) $1 \mathrm{M} \mathrm{LiPF}_{6}$ in EC:DMC $(1: 1)$ in the voltage range of $3.00-4.30 \mathrm{~V}$.

The obtained results show, that NMC/graphite cells containing $1 \mathrm{M} \mathrm{LiPF}_{6}$ in $\mathrm{BN}: \mathrm{EC}(9: 1)+3 \%$ FEC electrolyte display a remarkably stable cycling behavior at $5 \mathrm{C}$. In addition, a C-rate evaluation, in NMC/graphite cells, up to $20 \mathrm{C}$ was carried out. Figure 5 shows the C-rate evaluation of $1 \mathrm{M} \mathrm{LiPF}_{6}$ in BN:EC (9:1) + 3\% FEC compared to the reference organic carbonate-based $1 \mathrm{M} \mathrm{LiPF}_{6}$ in EC:DMC (1:1) electrolyte. Two types of C-rate evaluations were performed to determine whether the C-rate for charge (Figure $5 \mathrm{a}, \mathrm{b}$ ) or the C-rate for discharge (Figure $5 c, d$ ) has a more pronounced impact on the cycling stability of the NMC/graphite cells. In the first C-rate evaluation, the charge current is altered from $0.1 \mathrm{C}$ to $20 \mathrm{C}$, whereas the C-rate of the discharge step was kept constant. In the second C-rate evaluation, the $\mathrm{C}$-rate of the charge step remained constant while the $\mathrm{C}$-rate of the discharge step was changed. The $\mathrm{C}$-rate evaluation started with five formation cycles at $0.1 \mathrm{C}$ followed by five cycles at $1 \mathrm{C}$.

When comparing the overall performance of the considered NMC/graphite cells with $1 \mathrm{M} \mathrm{LiPF}_{6}$ in $\mathrm{BN}: \mathrm{EC}(9: 1)+3 \% \mathrm{FEC}$ and the $1 \mathrm{M} \mathrm{LiPF}_{6}$ in EC:DMC (1:1) electrolytes, a better C-rate performance is achieved for the BN-based electrolyte containing cells, as depicted in in Figure 5a. Especially at a C-rate (charge step) of 5C and 10C, the specific discharge capacity is much higher for the BN-based electrolyte containing cell. At low C-rates (charge step), the specific discharge capacities of both electrolyte containing cells are quite similar. At $0.1 \mathrm{C}$ and $0.2 \mathrm{C}$, the specific discharge capacity of the BN-based electrolyte containing cell has a value of $174 \mathrm{mAh} / \mathrm{g}$ and $160 \mathrm{mAh} / \mathrm{g}$, respectively. On the other hand, the organic carbonate-based electrolyte containing cell delivers a specific discharge capacity of $172 \mathrm{mAh} / \mathrm{g}$ at $0.1 \mathrm{C}$ and $154 \mathrm{mAh} / \mathrm{g}$ at $0.2 \mathrm{C}$, which is nearly similar to the cell containing $1 \mathrm{M} \mathrm{LiPF}_{6}$ in BN:EC (9:1) + 3\% FEC. At 5C and 10C, the better electrochemical performance of the BN-based electrolyte containing cell becomes clear, as a discharge capacity of $125 \mathrm{mAh} / \mathrm{g}$ is reached, compared to the $82 \mathrm{mAh} / \mathrm{g}$ for the organic carbonate-based counterpart. Even though the specific discharge capacity of the BN-based cell is not constant at 10C, the specific discharge capacity value is $62 \mathrm{mAh} / \mathrm{g}$, is higher compared to the $21 \mathrm{mAh} / \mathrm{g}$ obtained in the cell with the organic carbonate-based electrolyte. At a C-rate (charge step) of 20C, the BN-based electrolyte containing cell delivers a specific capacity of $8 \mathrm{mAh} / \mathrm{g}$. The decrease of $\mathrm{C}$-rate to $1 \mathrm{C}$ results in a stable cycling performance for both considered 
cell chemistries. Nevertheless, the cell containing BN-based formulation has a slightly higher specific discharge capacity. The corresponding Coulombic efficiency values are depicted in Figure 5b.
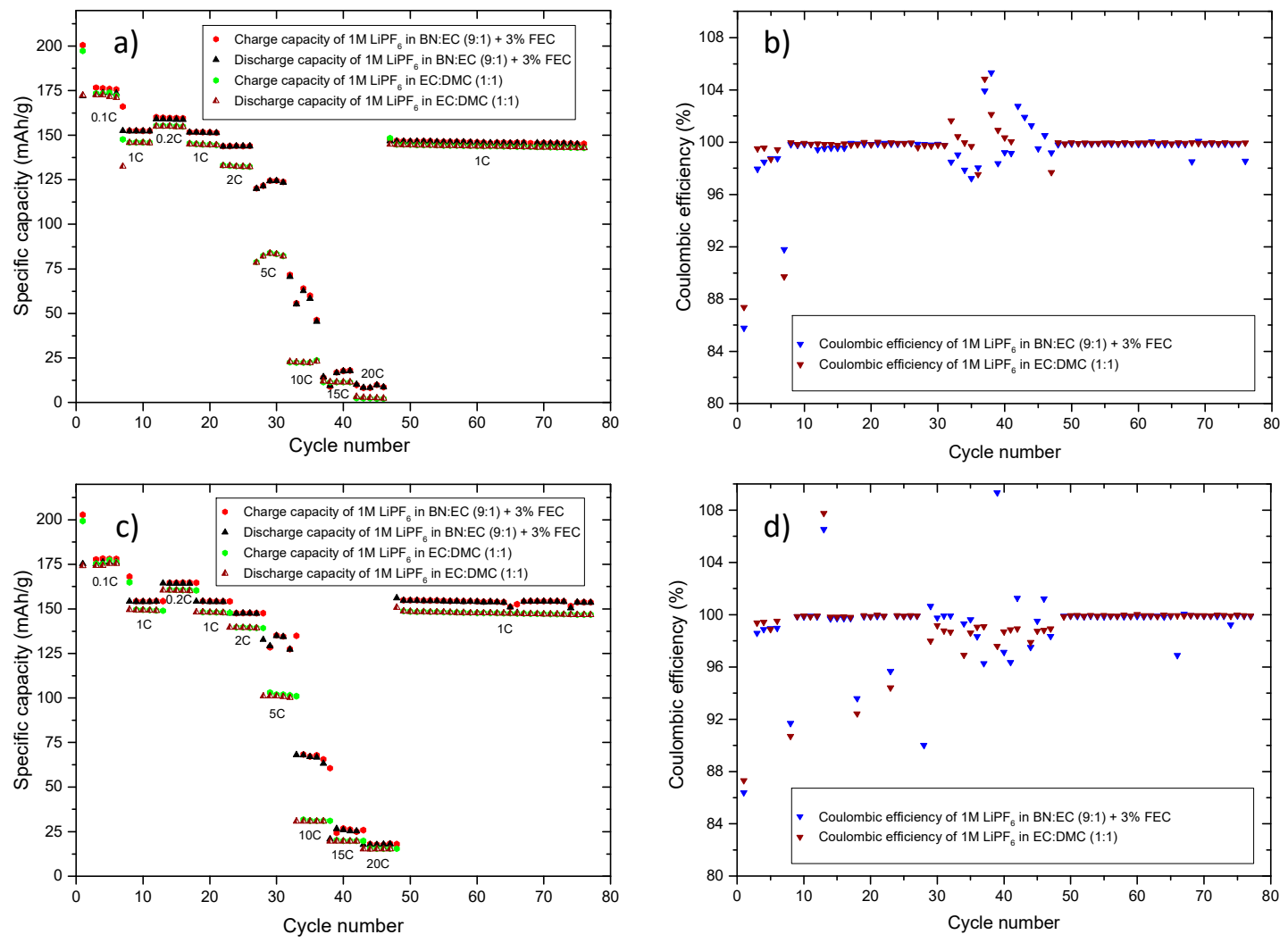

Figure 5. Cycling profiles and Coulombic efficiencies of the NMC/graphite cells containing $1 \mathrm{M} \mathrm{LiPF}_{6}$ in BN:EC (9:1) + 3\% FEC and 1M LiPF 6 in EC:DMC (1:1) electrolyte formulations cycled in a voltage range of 3.00-4.30 V using a C-rate procedure $(\mathbf{a}, \mathbf{b})$ the C-rate of the charge step is increasing while the C-rate of discharge step stays constant at $1 \mathrm{C}$ and a $\mathrm{C}$-rate procedure $(\mathbf{c}, \mathbf{d})$ where the $\mathrm{C}$-rate of the discharge step is increasing whereas the C-rate of the charge step stays constant at $1 \mathrm{C}$.

For the C-rate (of the discharge step) performance, a similar behavior can be observed (Figure 5c). At low C-rates (of the discharge step), the electrochemical performance of both cells is nearly similar, whereas with increasing C-rate (discharge step), the cell with the BN-based electrolyte shows a much better performance. At $5 \mathrm{C}$, a specific discharge capacity of $135 \mathrm{mAh} / \mathrm{g}$ is achieved. Increasing the discharge rate up to $10 \mathrm{C}$, a value of $67 \mathrm{mAh} / \mathrm{g}$ is reached for the $\mathrm{BN}$-based electrolyte containing cell. On the other side, the specific discharge capacity is much lower $(101 \mathrm{mAh} / \mathrm{g}$ and $29 \mathrm{mAh} / \mathrm{g}$, respectively) for the organic carbonate-based electrolyte containing cell. The decrease of the C-rate (discharge step) to 1C, results in stable cycling performance for both cell chemistries. Nevertheless, the cell containing BN-based electrolyte shows a higher specific discharge capacity $(155 \mathrm{mAh} / \mathrm{g}$ vs. $144 \mathrm{mAh} / \mathrm{g}$ ) at a C-rate (charge and discharge step) of one 1C after the 100th cycle. The corresponding Coulombic efficiency values are depicted in Figure 5d.

For both C-rate (both the charge and the discharge step) evaluations, it was shown that the cells containing a BN-based electrolyte outperform the organic carbonate-based counterpart. This is especially observed, at $5 \mathrm{C}$ and $10 \mathrm{C}$. Even at higher C-rates (15C and 20C), a cell containing $1 \mathrm{M}$ $\mathrm{LiPF}_{6}$ in $\mathrm{BN}: \mathrm{EC}(9: 1)+3 \%$ FEC electrolyte shows better electrochemical performance compared to the reference organic carbonate-based electrolyte counterpart. The simultaneous charge/discharge behavior of the considered BN-based cell and organic carbonate-based cell at different C-rates was evaluated further. As depicted in Figure 6, a similar behavior in terms of specific discharge capacity can be observed. An increase in the C-rate (of the charge and discharge step) results in higher difference 
between the specific discharge capacities of the cells containing BN-based electrolyte and the ones with the organic carbonate-based electrolyte. The cell containing $\mathrm{BN}$ as solvent shows much better cycling performance at higher C-rates (both charge and discharge), compared to the state-of-the-art electrolyte containing counterpart. At 1C, a specific discharge capacity of $154 \mathrm{mAh} / \mathrm{g}$ and $150 \mathrm{mAh} / \mathrm{g}$ for the cell containing organic carbonate-based electrolyte is achieved. By increasing the C-rate (both the charge and the discharge step) to $2 \mathrm{C}$, the specific discharge capacity reach values of $140 \mathrm{mAh} / \mathrm{g}$ and $129 \mathrm{mAh} / \mathrm{g}$, respectively, whereas an increase in the C-rate (both the charge and the discharge step to $10 \mathrm{C}$ results in a specific capacity value of $42 \mathrm{mAh} / \mathrm{g}$ and $22 \mathrm{mAh} / \mathrm{g}$, respectively. After increasing the C-rate (both the charge and the discharge step) to 20C, the BN-based electrolyte containing cell reaches a specific capacity of $9 \mathrm{mAh} / \mathrm{g}$ in contrast to $1 \mathrm{mAh} / \mathrm{g}$ for the state-of-the-art electrolyte containing counterpart. After the C-rate (both the charge and the discharge step) is decreased to $1 \mathrm{C}$ again, both electrolyte containing cells exhibit a stable cycling behavior (for both Coulombic efficiency as well as specific discharge capacity). During cycling with a C-rate (both the charge and the discharge step) of 1C, the cells deliver specific discharge capacity of $151 \mathrm{mAh} / \mathrm{g}$ in case of the BN-based electrolyte and $148 \mathrm{mAh} / \mathrm{g}$ for the organic carbonate-based electrolyte. The corresponding Coulombic efficiency values are depicted in Figure $6 \mathrm{~b}$. Table 1 summarizes the results obtained from graphs presented in Figures 5 and 6 for the NMC/graphite cells cycled with $1 \mathrm{M} \mathrm{LiPF}_{6}$ in BN:EC (9:1) + 3\% FEC and 1M $\mathrm{LiPF}_{6}$ in EC:DMC (1:1) electrolytes, respectively.
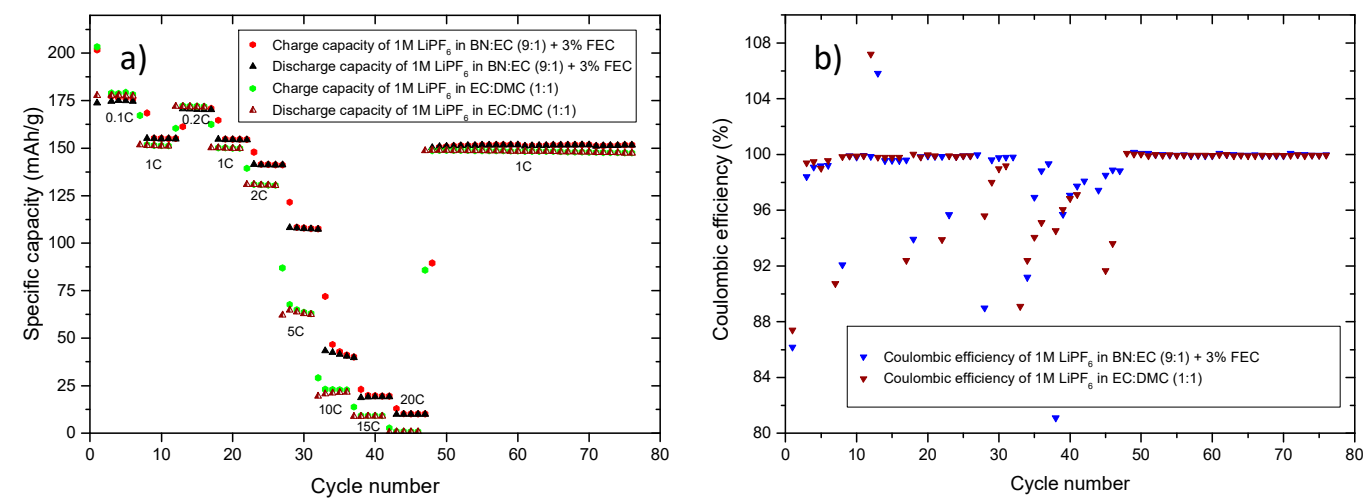

Figure 6. Cycling profiles (a) and Coulombic efficiencies (b) of NMC/graphite cells containing $1 \mathrm{M}$ $\mathrm{LiPF}_{6}$ in BN:EC (9:1) + 3\% FEC as well as $1 \mathrm{M} \mathrm{LiPF}_{6}$ in EC:DMC (1:1), respectively as electrolyte, cycled in the voltage range of $3.00-4.30 \mathrm{~V}$.

Table 1. Summary of solvents used in this work. Physical properties are reported at $25^{\circ} \mathrm{C}$ if not stated otherwise [55].

\begin{tabular}{ccccc}
\hline Structure & Compound & Abbreviation & $\eta(\mathbf{c P})$ & $\varepsilon_{\mathrm{r}}$ \\
\hline & Ethylene carbonate & EC & $1.9^{\mathrm{a}}[13]$ & $89.8^{\mathrm{a}}[9]$ \\
\hline & Dimethyl carbonate & DMC & $0.59[56]$ & $3.12[57]$ \\
\hline
\end{tabular}


As data listed in Table 2 show, the cells containing BN-based electrolytes deliver higher specific capacity values at higher C-rate compared to their state-of-the-art electrolyte counterparts. The C-rate (discharge step) evaluation setup leads to higher specific discharge capacities compared to the other two C-rate evaluations. This might be explained on the basis of the intercalation and deintercalation steps on graphite: the deintercalation process for graphite is always favored therefore, higher discharge capacities can be reached for both electrolytes [57]. Based on the obtained results, the main use for the BN-based electrolyte formulation would be in applications with high demands to power, fast charge ability or even both.

Table 2. Selected specific discharge capacities for the cells cycled with the BN-based electrolyte (cell a) and $1 \mathrm{M} \mathrm{LiPF}_{6}$ in EC:DMC (1:1) (cell b), respectively.

\begin{tabular}{ccccccc}
\hline \multirow{2}{*}{ C-Rate } & $\begin{array}{c}\text { C-Rate Performance } \\
\text { (Charge) Specific Capacity } \\
\text { (mAh/g) }\end{array}$ & $\begin{array}{c}\text { C-Rate Performance } \\
\text { (Discharge) Specific Capacity } \\
\text { (mAh/g) }\end{array}$ & $\begin{array}{c}\text { C-Rate Performance } \\
\text { (Charge/Discharge) Specific } \\
\text { Capacity (mAh/g) }\end{array}$ \\
\cline { 2 - 7 } & Cell a & Cell b & Cell a & Cell b & Cell a & Cell b \\
\hline $0.1 C$ & 176 & 172 & 177 & 174 & 175 & 177 \\
1C & 152 & 145 & 154 & 149 & 154 & 150 \\
2C & 144 & 133 & 148 & 139 & 140 & 129 \\
5C & 125 & 84 & 134 & 99 & 108 & 63 \\
10C & 62 & 23 & 68 & 31 & 42 & 22 \\
20C & 9 & 2 & 18 & 15 & 9 & 1 \\
\hline
\end{tabular}

As BN:EC (9:1) + 3\% FEC electrolyte containing cells show remarkable C-rate performance, long-time cycling experiments were conducted to enable deeper characterization of the electrochemical behavior of the considered cell chemistry. In Figure 7, two different long-term cycling measurements (1000 charge/discharge cycles) were performed for the BN-based electrolyte containing NMC/graphite cell as well as the state-of-the-art electrolyte containing counterpart.

The afore mentioned C-rate evaluation was performed without using a constant voltage (CV) step after the charge step. A CV step is typically used to enhance the capacity of the graphite slightly, making sure, that the graphite is fully lithiated [67].

The long-time cycling measurements depicted in Figure 7 show that, without $\mathrm{CV}$ step, the long term cycling performance of the $1 \mathrm{M} \mathrm{LiPF}_{6}$ in BN:EC (9:1) + 3\% FEC containing cells (Figure 7c) is comparable to the state of the art electrolyte based on $1 \mathrm{M} \mathrm{LiPF}_{6}$ in EC:DMC (1:1) cell counterparts, as depicted in Figure 7a. The 1st cycle Coulombic efficiency of the cell containing $1 \mathrm{M} \mathrm{LiPF}_{6}$ in EC:DMC (1:1) electrolyte (87\%) matches the Coulombic efficiency resulting with the $1 \mathrm{M} \mathrm{LiPF}_{6}$ in $\mathrm{BN}: \mathrm{EC}(9: 1)+$ $3 \%$ FEC electrolyte ( $87 \%$ Coulombic efficiency). Ninety-nine percent Coulombic efficiency is reached in the second cycle for the state-of-the-art electrolyte as well as for the BN-based counterpart. From this point onwards, the Coulombic efficiency values of both cells containing considered electrolytes are nearly similar, amounting to $\approx 99 \%$ during the long-term cycling performance. In the initial cycles, in which SEI formation takes place, a specific discharge capacity of $177 \mathrm{mAh} / \mathrm{g}$ is reached for the cell containing BN-based electrolyte, whereas the one with the EC:DMC-based electrolyte shows a specific discharge capacity of $173 \mathrm{mAh} / \mathrm{g}$. After the initial cycles (five cycles with $0.1 \mathrm{C}$ ), the cells were cycled with $1 \mathrm{C}$ until the 1000th charge/discharge cycle. For both cell chemistries, a stable long-term cycling is observed, with an absence of strong fading in capacity. In the 10th cycle, a specific discharge capacity of $155 \mathrm{mAh} / \mathrm{g}$ is reached and decreases slightly to $129 \mathrm{mAh} / \mathrm{g}$ in the last (1000th) cycle, for the cell with $1 \mathrm{M} \mathrm{LiPF}_{6}$ in BN:EC (9:1) + 3\% FEC as electrolyte. For the cell containing $1 \mathrm{M} \mathrm{LiPF}_{6}$ in EC:DMC (1:1) as electrolyte, a specific discharge capacity of $145 \mathrm{mAh} / \mathrm{g}$ in the 10th cycle and $135 \mathrm{mAh} / \mathrm{g}$ in the 1000th cycle is reached. Comparing the 10th cycle with the 1000th cycle, both electrolytes reach over $80 \%$ of the initial capacity, meeting the automotive requirements ( $80 \%$ state of health after 1000 charge/discharge cycles). 

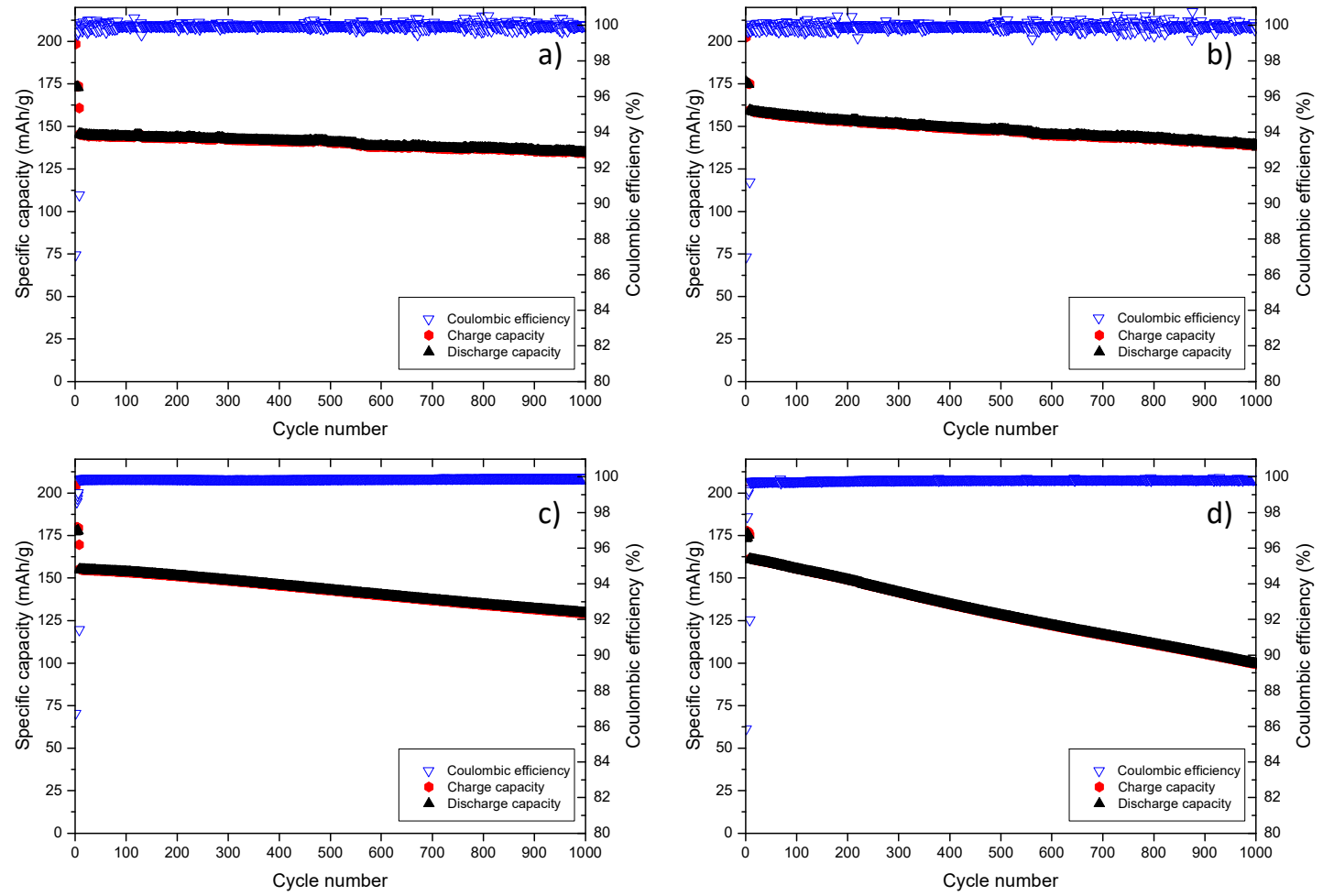

Figure 7. Long-term cycling profiles of the NMC/T44graphite cells containing electrolyte formulations: (a) $1 \mathrm{M} \mathrm{LiPF}_{6}$ in EC:DMC (1:1) without cyclic voltammetry (CV) step (cell a), (b) $1 \mathrm{M} \mathrm{LiPF}_{6}$ in EC:DMC (1:1) including CV step (cell b), (c) $1 \mathrm{M} \mathrm{LiPF}_{6}$ in BN:EC (9:1) + 3\% FEC without CV step (cell c), (d) $1 \mathrm{M}$ $\mathrm{LiPF}_{6}$ in BN:EC (9:1) + 3\% FEC including CV step (cell d) in the voltage range of 3.00-4.30 V.

For the long-term evaluations comprising a current-limited constant voltage step the results are different. The long-term cycling performance of the $1 \mathrm{M} \mathrm{LiPF}_{6}$ in BN:EC (9:1) + 3\% FEC (Figure 7d) is decreased compared to the state-of-the-art electrolyte-based cell depicted in Figure 7b. The 1st cycle Coulombic efficiency of the $1 \mathrm{M} \mathrm{LiPF}_{6}$ in EC:DMC (1:1) electrolyte $(87 \%)$ containing cell is similar to the Coulombic efficiency obtained for the $1 \mathrm{M} \mathrm{LiPF}_{6}$ in BN:EC (9:1) + 3\% FEC electrolyte $(86 \%$ Coulombic efficiency) based counterpart. The Coulombic efficiency of $99 \%$ for the state-of-the-art electrolyte containing cell is reached in the second cycle. For the BN-based electrolyte containing cell, a Coulombic efficiency amounts to o $99 \%$ only in the 4th cycle. From this point onwards, the Coulombic efficiency values of both electrolyte containing cells are nearly similar, $>99 \%$ prolong the long-term cycling. During the initial cycles, a specific discharge capacity of $174 \mathrm{mAh} / \mathrm{g}$ is reached for the BN-based electrolyte containing cell, whereas the one with the EC:DMC-based electrolytes displays a specific discharge capacity of $175 \mathrm{mAh} / \mathrm{g}$. After the initial cycles (five charge/discharge cycles with $0.1 \mathrm{C}$ ), the cells were cycled at $1 \mathrm{C}$ until the 1000th cycle. Both cells passed the long-term cycling procedure, thus indicating a good cycling performance. However, a slight fading of the cell with the BN-based electrolyte (Figure 7d) is noticeable. In the 10th cycle, a specific discharge capacity of $161 \mathrm{mAh} / \mathrm{g}$ is reached and decreases to $100 \mathrm{mAh} / \mathrm{g}$ in the 1000th cycle, for the cell with $1 \mathrm{M} \mathrm{LiPF}_{6}$ in BN:EC (9:1) + 3\% FEC as electrolyte. For the cell containing $1 \mathrm{M} \mathrm{LiPF}_{6}$ in EC:DMC (1:1) as electrolyte, a specific discharge capacity of $159 \mathrm{mAh} / \mathrm{g}$ in the 10th cycle and $139 \mathrm{mAh} / \mathrm{g}$ in the 1000th cycle is reached. Comparing the 10th cycle with the 1000th cycle only the state of the art electrolyte has reached over $80 \%$ of the initial capacity, meeting the automotive requirements [68]. Table 3 summarizes afore mentioned cycling performance and comperes both cycling procedures (with and without CV step).

The capacity retention values show, that a $\mathrm{CV}$ step deteriorates the electrochemical performance of the NMC/graphite cells. The same effect is observed with the reference electrolyte containing cell however, the effect is less pronounced. This outcome is explained by the time at which the cells 
remain at the cut-off voltage. For the cells cycled with a CV step, this duration is much larger and is leading to a pronounced degradation (shorter lifespan) of these cells. To correlate the obtained results with the surface chemistry of electrodes containing BN-based electrolyte, XPS sputter depth profiling of graphite electrodes was performed, to prove the stability of the electrolyte towards graphite. The electrochemical decomposition of considered BN-based electrolyte formulations on the graphite surface was analyzed by means of XPS (see Figure 8).

Table 3. 1st Coulombic efficiency, discharge capacity as well as capacity retention between the 10th and 1000th cycle for the reference electrolyte (cells a/b) and the nitrile-based electrolyte formulation (cells c/d) containing cells.

\begin{tabular}{ccccc}
\hline \multirow{2}{*}{ Selected Parameters } & Cell a & Cell b (CV) & Cell c & Cell d (CV) \\
\cline { 2 - 5 } & $\begin{array}{c}\text { (Reference } \\
\text { Electrolyte) }\end{array}$ & $\begin{array}{c}\text { (Reference } \\
\text { Electrolyte) }\end{array}$ & $\begin{array}{c}\text { (BN-Based } \\
\text { Electrolyte) }\end{array}$ & $\begin{array}{c}\text { (BN-Based } \\
\text { Electrolyte) }\end{array}$ \\
\hline $\begin{array}{c}\text { 1st Coulombic efficiency (\%) } \\
\text { Discharge capacity in } \\
\text { the10th cycle (mAh/g) }\end{array}$ & 87 & 87 & 87 & 86 \\
$\begin{array}{c}\text { Discharge capacity in the } \\
\text { 1000th cycle (mAh/g) }\end{array}$ & 145 & 159 & 155 & 161 \\
Capacity retention (\%) & 93 & 139 & 129 & 100 \\
\hline
\end{tabular}
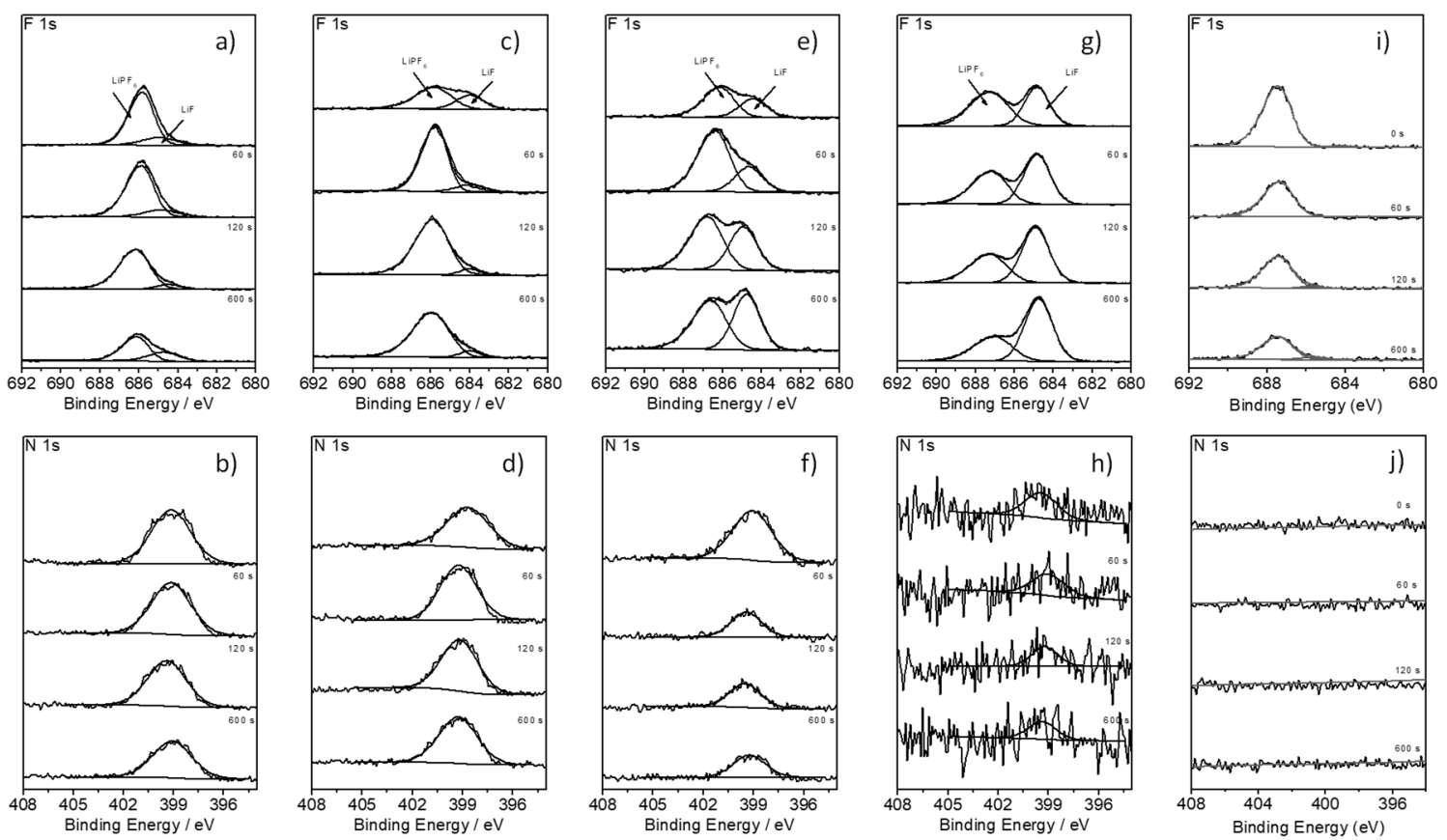

Figure 8. F 1s and N 1s core spectra of graphite electrodes, after five charge/discharge cycles at $0.1 \mathrm{C}$ in a NMC/graphite cells with different amounts of FEC in the electrolyte: $(\mathbf{a}, \mathbf{b}) 1 \mathrm{M} \mathrm{LiPF}_{6}$ in $\mathrm{BN},(\mathbf{c}, \mathbf{d}) 1 \mathrm{M}$ $\mathrm{LiPF}_{6}$ in $\mathrm{BN}+5 \% \mathrm{FEC},(\mathbf{e}, \mathbf{f}) 1 \mathrm{M} \mathrm{LiPF}_{6}$ in BN:EC (9:1) + 2\% FEC, (g,h), $1 \mathrm{M} \mathrm{LiPF} 6$ in BN:EC (9:1) + 3\% FEC and $(\mathbf{i}, \mathbf{j})$ pristine electrode.

Figure 8 depicts the XPS F 1s and $\mathrm{N}$ 1s core spectra of graphite electrode-based cells cycled in presence of a,b) $1 \mathrm{M} \mathrm{LiPF}_{6}$ in $\mathrm{BN}$; c,d) $1 \mathrm{M} \mathrm{LiPF}_{6}$ in $\mathrm{BN}$ with $5 \%$ FEC; e,f) $1 \mathrm{M} \mathrm{LiPF}_{6}$ in BN:EC $(9: 1)+2 \%$ FEC; as well as g,h) $1 \mathrm{M} \mathrm{LiPF}_{6}$ in BN:EC (9:1) + 3\% FEC as electrolyte. As reference spectra, the XPS F $1 \mathrm{~s}$ and $\mathrm{N} 1 \mathrm{~s}$ core spectra of a pristine graphite electrode (Figure 8i,j) are shown. In the F 1s spectra (Figure $8 \mathrm{i}$ ), a signal located at $687 \mathrm{eV}$ is observable, which can be attributed to the polyvinylidene difluoride (PVdF) binder [69]. The decrease of the peak intensity during sputtering is related to the decomposition of the binder during XPS measurement [70]. On the other hand, no nitrogen 
signal was observed on the pristine electrode surface (Figure 8j). In the F 1s spectra of the cycled electrodes (Figure $8 \mathrm{a}, \mathrm{c}, \mathrm{e}, \mathrm{g}$ ), an additional signal attributed to lithium fluoride ( $\mathrm{LiF}$ ), formed due to the decomposition of the conducting salt $\mathrm{LiPF}_{6}$, occurs at $685 \mathrm{eV}$. As depicted in Figure 8a,c the amount of $\mathrm{LiF}$ remains unaffected relatively to the intensity of the PVdF peak with increasing the sputter time. This could be explained by a limited degradation of $\mathrm{LiPF}_{6}$ in the $\mathrm{BN}$-based electrolytes without EC. Due to the severe decomposition of $\mathrm{BN}$, the corresponding peaks overlap the peaks assigned to the decomposition of $\mathrm{LiPF}_{6}$. In addition, in the N1s core spectra of the electrodes containing pure BN-based electrolyte (Figure 8b,d) a signal at $399 \mathrm{eV}$ is observed, attributed to the decomposition of the nitrile during cycling. In the absence of $\mathrm{BN}$ decomposition, the peak of $\mathrm{LiF}$ increases relatively to the PVdF peak with increasing the sputter time (Figure $8 \mathrm{e}, \mathrm{g}$ ), as $\mathrm{LiF}$ is the main component of the inorganic part of the SEI [70]. The increase of the LiF peak indicates absence of decomposition, meaning that a SEI was formed on graphite surface. Nevertheless, the $\mathrm{N} 1 \mathrm{~s}$ core spectra of the graphite electrode cycled with $1 \mathrm{M} \mathrm{LiPF}_{6}$ in $\mathrm{BN}: \mathrm{EC}(9: 1)+2 \% \mathrm{FEC}$, exhibit a peak $399 \mathrm{eV}$ related to $\mathrm{BN}$ decomposition, thus indicating that the formed SEI does not fully prevent the decomposition of the nitrile. By adding $3 \%$ FEC to the BN:EC (9:1) electrolyte formulation, the peak in the corresponding N1s core spectrum at $399 \mathrm{eV}$ disappears (Figure 8h), thus indicating an effective SEI formation, which prevents BN against decomposition. Table 4 lists the corresponding surface concentration given in arbitrary units (a.u.).

Table 4. Surface concentration on graphite in arbitrary unit (a.u.) of the performed XPS measurements using different BN-based electrolytes.

\begin{tabular}{|c|c|c|c|c|}
\hline \multicolumn{5}{|c|}{ Pure BN-Based Electrolyte: Surface Concentration (a.u.) } \\
\hline Sputter time & $\mathbf{0 s}$ & $60 \mathrm{~s}$ & $120 \mathrm{~s}$ & $600 \mathrm{~s}$ \\
\hline LIF & $2.13(0.25)$ & $0.99(0.71)$ & $1.28(0.05)$ & $1.84(0.66)$ \\
\hline N $1 \mathrm{~s}$ & $10.74(0.98)$ & $10.06(1.24)$ & $8.69(2.07)$ & $9.14(0.38)$ \\
\hline \multicolumn{5}{|c|}{ BN + 5\%FEC based electrolyte: surface concentration (a.u.) } \\
\hline Sputter time & $0 \mathrm{~s}$ & $60 \mathrm{~s}$ & $120 \mathrm{~s}$ & $600 \mathrm{~s}$ \\
\hline LIF & $3.80(1.02)$ & $2.14(2.43)$ & $1.26(0.45)$ & $4.00(0.53)$ \\
\hline $\mathrm{N} 1 \mathrm{~s}$ & $11.83(0.58)$ & $12.26(0.99)$ & $9.37(0.32)$ & $9.78(0.73)$ \\
\hline \multicolumn{5}{|c|}{ BN:EC (9:1) + 2\%FEC based electrolyte: surface concentration (a.u.) } \\
\hline Sputter time & $0 \mathrm{~s}$ & $60 \mathrm{~s}$ & $120 \mathrm{~s}$ & $600 \mathrm{~s}$ \\
\hline LIF & $4.37(0.79)$ & $7.88(0.22)$ & $8.79(0.28)$ & $9.90(0.16)$ \\
\hline N $1 \mathrm{~s}$ & $3.53(0.35)$ & $3.71(0.28)$ & $3.22(0.11)$ & $3.28(0.21)$ \\
\hline \multicolumn{5}{|c|}{ BN:EC (9:1) + 3\%FEC based electrolyte: surface concentration (a.u.) } \\
\hline Sputter time & $0 \mathrm{~s}$ & $60 \mathrm{~s}$ & $120 \mathrm{~s}$ & $600 \mathrm{~s}$ \\
\hline LIF & $12.15(0.47)$ & $16.49(1.03)$ & $18.40(1.16)$ & $20.61(0.52)$ \\
\hline $\mathrm{N} 1 \mathrm{~s}$ & $0.44(0.11)$ & $0.38(0.11)$ & $0.27(0.30)$ & $0.25(0.25)$ \\
\hline \multicolumn{5}{|c|}{ Reference electrode (pristine): surface concentration (a.u.) } \\
\hline Sputter time & $0 \mathrm{~s}$ & $60 \mathrm{~s}$ & $120 \mathrm{~s}$ & $600 \mathrm{~s}$ \\
\hline LIF & $0.86(0.84)$ & $2.33(0.73)$ & $1.52(1.47)$ & $1.32(0.93)$ \\
\hline $\mathrm{N} 1 \mathrm{~s}$ & $0(0)$ & $0(1.12)$ & $0(0)$ & $0(0)$ \\
\hline
\end{tabular}

For the electrodes with pure BN-based electrolyte, as well as for the electrolyte formulation containing $5 \% \mathrm{FEC}$, only small amounts of $\mathrm{LiF}$ were detected. The origin of the spectra can be dedicated to the decomposition of small amounts of the conducting salt $\mathrm{LiPF}_{6}$. The $\mathrm{N} 1 \mathrm{~s}$ surface concentration for both electrolytes indicates a severe decomposition of BN. Without formation of an effective SEI, an ongoing decomposition of the solvent (BN) takes place. For the electrolyte formulations BN:EC (9:1) with addition of $2 \%$ and $3 \%$ FEC respectively, the amount of $\mathrm{LiF}$ increases during sputtering $[70,71]$. The intensity of the $\mathrm{N} 1 \mathrm{~s}$ signal decreases for both electrolytes corresponding to a less pronounced 
decomposition of the $\mathrm{BN}$-solvent. However, regarding the $\mathrm{N}$ 1s surface concentration, the addition of $2 \%$ FEC is not enough for the formation of an effective SEI on graphite. The $\mathrm{N} 1 \mathrm{~s}$ surface concentration of the formulation containing $3 \% \mathrm{FEC}$ is comparable to the $\mathrm{N} 1$ s surface concentration of the reference electrode, however, both do not show a significant signal.

\section{Conclusions}

With two successfully tuned BN-based electrolyte formulations (one used in half-cell and the other in full-cell configuration), the decomposition on both lithium metal and graphite, could be prevented. Both electrolytes were comparable or even better compared to the state-of-the-art organic carbonate-based electrolyte. In half cell experiments, $1 \mathrm{M} \mathrm{LiPF}_{6}$ in BN:FEC (1:1) containing cell showed the most promising results. EC was compared to FEC, due to its lower passivation capability towards metallic lithium, not suitable to protect $\mathrm{BN}$ against decomposition. Nevertheless, $1 \mathrm{M} \mathrm{LiPF}_{6}$ in $\mathrm{BN}: \mathrm{FEC}$ formulation showed lower ion conductivity values compared to BN:EC counterparts. Especially at low temperatures around $0{ }^{\circ} \mathrm{C}$, the conductivity of the BN:EC-based electrolytes was at least $32 \%$ higher $(7.69 \mathrm{mS} / \mathrm{cm})$ compared to the BN:FEC-based and the organic carbonate-based electrolyte $(5.83 \mathrm{mS} / \mathrm{cm})$. Since the main focus of this paper is related to the possible the automotive applicability of $\mathrm{BN}$, investigations in $\mathrm{NMC} /$ graphite cells containing BN:EC-based electrolytes were studied in detail. In each investigation, the cell containing $1 \mathrm{M} \mathrm{LiPF}_{6}$ in $\mathrm{BN}: \mathrm{EC}(9: 1)+3 \% \mathrm{FEC}$ showed a superior high performance compared to the organic-carbonate-based counterpart. To match automotive requirements, a C-rate evaluation of $5 \mathrm{C}$ was performed. It was shown, that the average specific discharge capacity at $5 \mathrm{C}$ amounted to $\approx 103 \mathrm{mAh} / \mathrm{g}$ for the investigated BN-based electrolyte containing cell, which was nearly twice the capacity of the cell with the reference electrolyte $(\approx 66 \mathrm{mAh} / \mathrm{g})$. Further, a C-rate evaluation up to 20C was performed. The cells containing investigated BN-based electrolyte formulation showed a superior C-rate performance compared to the organic state of the art counterpart. In addition, the $\mathrm{CV}$ step in the CCCV measurements, typically used in case of organic carbonate-based electrolyte containing cells, was investigated. It was found out, that a CV step increases the charge/discharge capacity at the beginning of the cycling procedure so that more lithium ions can be intercalated into graphite. Nevertheless, the CV step reduces the overall cycle-life of the cell as well, due to the pronounced electrolyte degradation. In the long-term cycling experiment (Figure $7 \mathrm{c}, \mathrm{d}$ ) the advantage of the CV step is lost after the 150th cycle. From the 150th cycle onwards the capacity of the cell cycled without CV step is higher compared to the cell cycled with CV step.

XPS analysis of the NMC electrodes complements well to the electrochemical characterization of the BN-based electrolytes, showing that a minimum amount of $3 \% \mathrm{FEC}$ is needed to prevent the BN-based electrolyte formulation of $1 \mathrm{M} \mathrm{LiPF}_{6}$ in $\mathrm{BN}: \mathrm{EC}$ (9:1) from decomposition on graphite in NMC/graphite cell setup.

Author Contributions: P.H., I.C.-L. and M.W. conceived and designed theexperiments; P.H. and L.I. performed the experiments; P.H., L.I., I.C.-L. and M.W. analyzed the data; P.H. and I.C.-L. wrote the paper.

Funding: Financial support by the German Federal Ministry for Education and Research (BMBF) within the project Electrolyte Lab 4E (project reference $03 X 4632$ ) is gratefully acknowledged.

Conflicts of Interest: The authors declare no conflict of interest.

\section{References}

1. Winter, M.; Brodd, R.J. What are batteries, fuel cells, and supercapacitors? Chem. Rev. 2004, 104, 4245-4269. [CrossRef] [PubMed]

2. Andre, D.; Kim, S.-J.; Lamp, P.; Lux, S.F.; Maglia, F.; Paschos, O.; Stiaszny, B. Future generations of cathode materials: an automotive industry perspective. J. Mater. Chem. A 2015, 3, 6709-6732. [CrossRef]

3. Schmuch, R.; Wagner, R.; Hörpel, G.; Placke, T.; Winter, M. Performance and cost of materials for lithium-based rechargeable automotive batteries. Nat. Energy 2018, 3, 267. [CrossRef]

4. Winter, M.; Barnett, B.; Xu, K. Before Li ion batteries. Chem. Rev. 2018, 118, 11433-11456. [CrossRef] [PubMed] 
5. Lu, L.; Han, X.; Li, J.; Hua, J.; Ouyang, M. A review on the key issues for lithium-ion battery management in electric vehicles. J. Power Sources 2013, 226, 272-288. [CrossRef]

6. Placke, T.; Kloepsch, R.; Dühnen, S.; Winter, M. Lithium ion, lithium metal, and alternative rechargeable battery technologies: the odyssey for high energy density. J. Solid State Electrochem. 2017, 21, 1939-1964. [CrossRef]

7. Betz, J.; Bieker, G.; Meister, P.; Placke, T.; Winter, M.; Schmuch, R. Theoretical versus Practical Energy: A Plea for More Transparency in the Energy Calculation of Different Rechargeable Battery Systems. Adv. Energy Mater. 2019, 9, 1803170. [CrossRef]

8. Wagner, R.; Preschitschek, N.; Passerini, S.; Leker, J.; Winter, M. Current research trends and prospects among the various materials and designs used in lithium-based batteries. J. Appl. Electrochem. 2013, 43, 481-496. [CrossRef]

9. Xu, K. Nonaqueous liquid electrolytes for lithium-based rechargeable batteries. Chem. Rev. 2004, 104, 4303-4417. [CrossRef]

10. Wen, J.; Yu, Y.; Chen, C. A Review on Lithium-Ion Batteries Safety Issues: Existing Problems and Possible Solutions. Mater. Express 2012, 2, 197-212. [CrossRef]

11. Wrodnigg, G.H.; Besenhard, J.O.; Winter, M. Ethylene sulfite as electrolyte additive for lithium-ion cells with graphitic anodes. J. Electrochem. Soc. 1999, 146, 470-472. [CrossRef]

12. Chawla, N.; Bharti, N.; Singh, S. Recent advances in non-flammable electrolytes for safer lithium-ion batteries. Batteries 2019, 5, 19. [CrossRef]

13. $\mathrm{Xu}, \mathrm{K}$. Electrolytes and Interphases in Li-Ion Batteries and Beyond. Chem. Rev. 2014, 114, 11503-11618. [CrossRef] [PubMed]

14. Cekic-Laskovic, I.; von Aspern, N.; Imholt, L.; Kaymaksiz, S.; Oldiges, K.; Rad, B.R.; Winter, M. Synergistic effect of blended components in nonaqueous electrolytes for lithium ion batteries. Top. Curr. Chem. 2017, 375, 37. [CrossRef] [PubMed]

15. Xue, L.; Lee, S.-Y.; Zhao, Z.; Angell, C.A. Sulfone-carbonate ternary electrolyte with further increased capacity retention and burn resistance for high voltage lithium ion batteries. J. Power Sources 2015, 295, 190-196. [CrossRef]

16. Lewandowski, A.; Kurc, B.; Stepniak, I.; Swiderska-Mocek, A. Properties of Li-graphite and LiFePO4 electrodes in LiPF6-sulfolane electrolyte. Electrochim. Acta 2011, 56, 5972-5978. [CrossRef]

17. Abu-Lebdeh, Y.; Davidson, I. High-Voltage Electrolytes Based on Adiponitrile for Li-Ion Batteries. J. Electrochem. Soc. 2009, 156, A60-A65. [CrossRef]

18. Winter, M.; Novák, P. Chloroethylene Carbonate, a Solvent for Lithium-Ion Cells, Evolving $\mathrm{CO}_{2}$ during Reduction. J. Electrochem. Soc. 1998, 145, L27-L30. [CrossRef]

19. Wrodnigg, G.H.; Besenhard, J.O.; Winter, M. Cyclic and acyclic sulfites: new solvents and electrolyte additives for lithium ion batteries with graphitic anodes? J. Power Sources 2001, 97, 592-594. [CrossRef]

20. Krämer, E.; Passerini, S.; Winter, M. Dependency of aluminum collector corrosion in lithium ion batteries on the electrolyte solvent. ECS Electrochem. Lett. 2012, 1, C9-C11. [CrossRef]

21. Winter, M.; Moeller, K.-C.; Besenhard, J.O. Lithium Batteries: Science and Technology; Nazri, G.A., Pistoia, G., Eds.; Kluwer Academic Publishers: New York, NY, USA, 2004; p. 144.

22. Safa, M.; Chamaani, A.; Chawla, N.; El-Zahab, B. Polymeric ionic liquid gel electrolyte for room temperature lithium battery applications. Electrochim. Acta 2016, 213, 587-593. [CrossRef]

23. Safa, M.; Adelowo, E.; Chamaani, A.; Chawla, N.; Herndon, M.; Baboukani, A.; Wang, C.; El-Zahab, B. Poly (Ionic Liquid) based Composite Gel Electrolyte for Lithium Batteries. ChemElectroChem 2019, 6, 3319-3332. [CrossRef]

24. Hilbig, P.; Ibing, L.; Wagner, R.; Winter, M.; Cekic-Laskovic, I. Ethyl methyl sulfone-based electrolytes for lithium ion battery applications. Energies 2017, 10, 1312. [CrossRef]

25. Yamada, Y.; Furukawa, K.; Sodeyama, K.; Kikuchi, K.; Yaegashi, M.; Tateyama, Y.; Yamada, A. Unusual Stability of Acetonitrile-Based Superconcentrated Electrolytes for Fast-Charging Lithium-Ion Batteries. J. Am.Chem. Soc. 2014, 136, 5039-5046. [CrossRef]

26. Isken, P.; Dippel, C.; Schmitz, R.; Schmitz, R.W.; Kunze, M.; Passerini, S.; Winter, M.; Lex-Balducci, A. High flash point electrolyte for use in lithium-ion batteries. Electrochim. Acta 2011, 56, 7530-7535. [CrossRef] 
27. Schmitz, R.W.; Murmann, P.; Schmitz, R.; Müller, R.; Krämer, L.; Kasnatscheew, J.; Isken, P.; Niehoff, P.; Nowak, S.; Röschenthaler, G.-V.; et al. Investigations on novel electrolytes, solvents and SEI additives for use in lithium-ion batteries: Systematic electrochemical characterization and detailed analysis by spectroscopic methods. Prog. Solid State Chem. 2014, 42, 65-84. [CrossRef]

28. Korepp, C.; Santner, H.; Fujii, T.; Ue, M.; Besenhard, J.; Möller, K.-C.; Winter, M. 2-Cyanofuran-A novel vinylene electrolyte additive for PC-based electrolytes in lithium-ion batteries. J. Power Sources 2006, 158, 578-582. [CrossRef]

29. Brox, S.; Röser, S.; Streipert, B.; Hildebrand, S.; Rodehorst, U.; Qi, X.; Wagner, R.; Winter, M.; Cekic-Laskovic, I. Innovative, Non-Corrosive LiTFSI Cyanoester-Based Electrolyte for Safer $4 \mathrm{~V}$ Lithium-Ion Batteries. ChemElectroChem 2017, 4, 304-309. [CrossRef]

30. Brox, S.; Röser, S.; Husch, T.; Hildebrand, S.; Fromm, O.; Korth, M.; Winter, M.; Cekic-Laskovic, I. Alternative Single-Solvent Electrolytes Based on Cyanoesters for Safer Lithium-Ion Batteries. ChemSusChem 2016, 9, 1704-1711. [CrossRef]

31. Pohl, B.; Grünebaum, M.; Drews, M.; Passerini, S.; Winter, M.; Wiemhöfer, H.D. Nitrile functionalized silyl ether with dissolved LiTFSI as new electrolyte solvent for lithium-ion batteries. Electrochim. Acta 2015, 180, 795-800. [CrossRef]

32. Kirshnamoorthy, A.N.; Oldiges, K.; Winter, M.; Heuer, A.; Cekic-Laskovic, I.; Holm, C.; Smiatek, J. Electrolyte solvents for high voltage lithium ion batteries: ion correlation and specific anion effects in adiponitrile. Chem. Chem. Phys. 2018, 20, 25701-25715. [CrossRef] [PubMed]

33. Oldiges, K.; von Aspern, N.; Cekic-Laskovic, I.; Winter, M.; Brunklaus, G. Impact of Trifluoromethylation of Adiponitrile on Aluminum Dissolution Behavior in Dinitrile-Based Electrolytes. J. Electrochem. Soc. 2018, 165, A3773-A3781. [CrossRef]

34. Santner, H.J.; Möller, K.C.; Ivanco, J.; Ramsey, M.G.; Netzer, F.P.; Yamaguchi, S.; Besenhard, J.O.; Winter, M. Acrylic acid nitrile, a film-forming electrolyte component for lithium-ion batteries, which belongs to the family of additives containing vinyl groups. J. Power Sources 2003, 119, 368-372. [CrossRef]

35. Peled, E. The Electrochemical Behavior of Alkali and Alkaline Earth Metals in Nonaqueous Battery Systems-The Solid Electrolyte Interphase Model. J. Electrochem. Soc. 1979, 126, 2047-2051. [CrossRef]

36. Peled, E.; Golodnitsky, D.; Ardel, G. Advanced model for solid electrolyte interphase electrodes in liquid and polymer electrolytes. J. Electrochem. Soc. 1997, 144, L208-L210. [CrossRef]

37. Zhang, S.S.; Ding, M.S.; Xu, K.; Allen, J.; Jow, T.R. Understanding solid electrolyte interface film formation on graphite electrodes. Electrochem. Solid State Lett. 2001, 4, A206-A208. [CrossRef]

38. Winter, M.; Appel, W.K.; Evers, B.; Hodal, T.; Moller, K.C.; Schneider, I.; Wachtler, M.; Wagner, M.R.; Wrodnigg, G.H.; Besenhard, J.O. Studies on the anode/electrolyte interface in lithium ion batteries. Chem. Mon. 2001, 132, 473-486. [CrossRef]

39. Li, F.S.; Wu, Y.S.; Chou, J.; Winter, M.; Wu, N.L. A mechanically robust and highly ion-conductive polymer-blend coating for high-power and long-life lithium-ion battery anodes. Adv. Mater 2015, 27, $130-137$. [CrossRef]

40. Winter, M. The solid electrolyte interphase-the most important and the least understood solid electrolyte in rechargeable Li batteries. Z. Phys. Chem. 2009, 223, 1395-1406. [CrossRef]

41. Santner, H.J.; Korepp, C.; Winter, M.; Besenhard, J.O.; Möller, K.-C. In-situ FTIR investigations on the reduction of vinylene electrolyte additives suitable for use in lithium-ion batteries. Anal. Bioanal. Chem. 2004, 379, 266-271. [CrossRef]

42. Märkle, W.; Lu, C.-Y.; Novák, P. Morphology of the Solid Electrolyte Interphase on Graphite in Dependency on the Formation Current. J. Electrochem. Soc. 2011, 158, A1478-A1482. [CrossRef]

43. Besenhard, J.O.; Wagner, M.W.; Winter, M.; Jannakoudakis, A.D.; Jannakoudakis, P.D.; Theodoridou, E. Inorganic Film-Forming Electrolyte Additives Improving the Cycling Behavior of Metallic Lithium Electrodes and the Self-Discharge of Carbon Lithium Electrodes. J. Power Sources 1993, 44, 413-420. [CrossRef]

44. Wang, K.; Xing, L.; Zhi, H.; Cai, Y.; Yan, Z.; Cai, D.; Zhou, H.; Li, W. High stability graphite/electrolyte interface created by a novel electrolyte additive: A theoretical and experimental study. Electrochim. Acta 2018, 262, 226-232. [CrossRef]

45. Wang, Y.; Nakamura, S.; Tasaki, K.; Balbuena, P.B. Theoretical Studies to Understand Surface Chemistry on Carbon Anodes for Lithium-Ion Batteries: How Does Vinylene Carbonate Play Its Role as an Electrolyte Additive? J. Am.Chem. Soc. 2002, 124, 4408-4421. [CrossRef] [PubMed] 
46. Aurbach, D.; Gamolsky, K.; Markovsky, B.; Gofer, Y.; Schmidt, M.; Heider, U. On the use of vinylene carbonate (VC) as an additive to electrolyte solutions for Li-ion batteries. Electrochim. Acta 2002, 47, 1423-1439. [CrossRef]

47. Zhang, L.; Ma, Y.; Cheng, X.; Zuo, P.; Cui, Y.; Guan, T.; Du, C.; Gao, Y.; Yin, G. Enhancement of high voltage cycling performance and thermal stability of $\mathrm{LiNi} 1 / 3 \mathrm{Co} 1 / 3 \mathrm{Mn} 1 / 3 \mathrm{O} 2$ cathode by use of boron-based additives. Solid State Ionics 2014, 263, 146-151. [CrossRef]

48. Meister, P.; Qi, X.; Kloepsch, R.; Krämer, E.; Streipert, B.; Winter, M.; Placke, T. Anodic Behavior of the Aluminum Current Collector in Imide-Based Electrolytes: Influence of Solvent, Operating Temperature, and Native Oxide-Layer Thickness. ChemSusChem 2017, 10, 804-814. [CrossRef]

49. Markevich, E.; Salitra, G.; Aurbach, D. Fluoroethylene carbonate as an important component for the formation of an effective solid electrolyte interphase on anodes and cathodes for advanced Li-ion batteries. ACS Energy Lett. 2017, 2, 1337-1345. [CrossRef]

50. Zugmann, S.; Moosbauer, D.; Amereller, M.; Schreiner, C.; Wudy, F.; Schmitz, R.; Schmitz, R.; Isken, P.; Dippel, C.; Muller, R.; et al. Electrochemical characterizaiton of electrolytes for lithium-ion batteries based on lithium difluoromono(oxalato)borate. J. Power Sources 2011, 196, 1417-1424. [CrossRef]

51. Dagger, T.; Grützke, M.; Reichert, M.; Haetge, J.; Nowak, S.; Winter, M.; Schappacher, F.M. Investigation of lithium ion battery electrolytes containing flame retardants in combination with the film forming electrolyte additives vinylene carbonate, vinyl ethylene carbonate and fluoroethylene carbonate. J. Power Sources 2017, 372, 276-285. [CrossRef]

52. Heine, J.; Hilbig, P.; Qi, X.; Niehoff, P.; Winter, M.; Bieker, P. Fluoroethylene carbonate as electrolyte additive in tetraethylene glycol dimethyl ether based electrolytes for application in lithium ion and lithium metal batteries. J. Electrochem. Soc. 2015, 162, A1094-A1101. [CrossRef]

53. Kasnatscheew, J.; Schmitz, R.W.; Wagner, R.; Winter, M.; Schmitz, R. Fluoroethylene Carbonate as an Additive for $\gamma$-Butyrolactone Based Electrolytes. J. Electrochem. Soc. 2013, 160, A1369-A1374. [CrossRef]

54. Winter, M.; Novak, P.; Monnier, A. Graphites for lithium-ion cells: The correlation of the first-cycle charge loss with the Brunauer-Emmett-Teller surface area. J. Electrochem. Soc. 1998, 145, 428-436. [CrossRef]

55. Hall, D.S.; Eldesoky, A.; Logan, E.R.; Tonita, E.M.; Ma, X.; Dahn, J.R. Exploring Classes of Co-Solvents for Fast-Charging Lithium-Ion Cells. J. Electrochem. Soc. 2018, 165, A2365-A2373. [CrossRef]

56. Pal, A.; Kumar, A. Excess Molar Volumes, Viscosities, and Refractive Indices of Diethylene Glycol Dimethyl Ether with Dimethyl Carbonate, Diethyl Carbonate, and Propylene Carbonate at $(298.15,308.15$, and 318.15) K. J. Chem. Eng. Data 1998, 43, 143-147. [CrossRef]

57. Smart, M.C.; Ratnakumar, B.V.; Surampudi, S. Electrolytes for Low-Temperature Lithium Batteries Based on Ternary Mixtures of Aliphatic Carbonates. J. Electrochem. Soc. 1999, 146, 486-492. [CrossRef]

58. Ue, M.; Sasaki, Y.; Tanaka, Y.; Morita, M. Nonaqueous Electrolytes with Advances in Solvents. In Electrolytes for Lithium and Lithium-Ion Batteries; Jow, T.R., Xu, K., Borodin, O., Ue, M., Eds.; Springer: New York, NY, USA, 2014; pp. 93-165.

59. D'Aprano, A.; Fuoss, R.M. Conductance in isodielectric mixtures. I.n-butyronitrile with dioxane, benzene, and carbon tetrachloride. J. Solut. Chem. 1974, 3, 45-55. [CrossRef]

60. Wyman, J. Polarization and Dielectric Constant of Liquids. J. Am.Chem. Soc. 1936, 58, 1482-1486. [CrossRef]

61. Grünebaum, M.; Buchheit, A.; Lürenbaum, C.; Winter, M.; Wiemhöfer, H.-D. Ester-Based Battery Solvents in Contact with Metallic Lithium: Effect of Water and Alcohol Impurities. J. Phys. Chem. 2019, 123, 7033-7044. [CrossRef]

62. Bieker, G.; Winter, M.; Bieker, P. Electrochemical in situ investigations of SEI and dendrite formation on the lithium metal anode. Phys. Chem. Chem. Phys. 2015, 17, 8670-8679. [CrossRef] [PubMed]

63. $\mathrm{Xu}, \mathrm{K} . ;$ Ding, S.P.; Jow, T.R. Toward reliable values of electrochemical stability limits for electrolytes. J. Electrochem. Soc. 1999, 146, 4172-4178. [CrossRef]

64. Kasnatscheew, J.; Streipert, B.; Röser, S.; Wagner, R.; Laskovic, I.C.; Winter, M. Determining oxidative stability of battery electrolytes: validity of common electrochemical stability window (ESW) data and alternative strategies. Phys. Chem. Chem. Phys. 2017, 19, 16078-16086. [CrossRef] [PubMed]

65. Hilbig, P.; Ibing, L.; Streipert, B.; Wagner, R.; Winter, M.; Cekic-Laskovic, I. Acetonitrile-Based Electrolytes for Lithium-Ion Battery Application. Curr. Top. Electrochem. 2018, 20, 1-30. 
66. Meister, P.; Jia, H.; Li, J.; Kloepsch, R.; Winter, M.; Placke, T. Best Practice: Performance and Cost Evaluation of Lithium Ion Battery Active Materials with Special Emphasis on Energy Efficiency. Chem. Mater. 2016, 28, 7203-7217. [CrossRef]

67. Besenhard, J.O.; Winter, M. Insertion reactions in advanced electrochemical energy storage. Pure Appl. Chem. 1998, 70, 603-608. [CrossRef]

68. Mller, T. Lithium ion battery automotive applications and requirements. In Proceedings of the Seventeenth Annual Battery Conference on Applications and Advances, Long Beach, CA, USA, 18 January 2002; pp. 113-118.

69. Wachtler, M.; Wagner, M.R.; Schmied, M.; Winter, M.; Besenhard, J.O. The effect of the binder morphology on the cycling stability of Li-alloy composite electrodes. J. Electroanal. Chem. 2001, 510, 12-19. [CrossRef]

70. Niehoff, P.; Passerini, S.; Winter, M. Interface Investigations of a Commercial Lithium Ion Battery Graphite Anode Material by Sputter Depth Profile X-ray Photoelectron Spectroscopy. Langmuir 2013, 29, 5806-5816. [CrossRef] [PubMed]

71. Niehoff, P.; Winter, M. Composition and Growth Behavior of the Surface and Electrolyte Decomposition Layer of/on a Commercial Lithium Ion Battery LixNi1/3Mn1/3Co1/3O2 Cathode Determined by Sputter Depth Profile X-ray Photoelectron Spectroscopy. Langmuir 2013, 29, 15813-15821. [CrossRef]

(C) 2019 by the authors. Licensee MDPI, Basel, Switzerland. This article is an open access article distributed under the terms and conditions of the Creative Commons Attribution (CC BY) license (http://creativecommons.org/licenses/by/4.0/). 